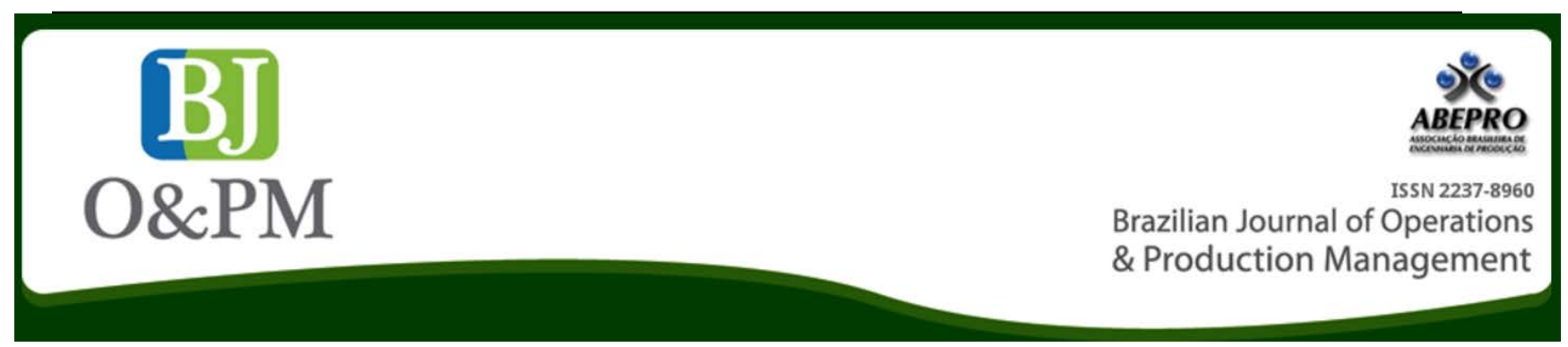

\title{
INDICATORS OF BUSINESS PERFORMANCE: A VIEW FROM THE EXPERTS OF THE FEDERAL FLUMINENSE UNIVERSITY
}

\author{
Vivian Magalhães Rodriguesa; Ualison Rébula Oliveira ${ }^{a}$ \\ ${ }^{a}$ Federal Fluminense University (UFF) - Niterói, RJ, Brasil
}

\begin{abstract}
During the technological evolution of the means of production and services, indicators of performance were usually used - from the more intuitive to the most elaborate forms - to convey information and support decisions. Verifying the difficulty of Micro and Small Enterprises (MSE) on planning strategies, generating data and implementing information for decision support systems, there is a need to prepare an introductory set of performance indicators for this important kind of organization - as shown in this paper. To achieve this goal, we studied the Balanced Scorecard - a model of performance indicators highly diffused worldwide - to choose the most popular indicators for Micro and Small Enterprises. The main results of this study are fifteen performance indicators targeted in the four perspectives of the Balanced Scorecard, which in the opinion of experts on the subject are ideal for introducing support in decision making for micro and small organizations strategies. In this context, this article aimed to raise the opinion of PhDs from the University Federal Fluminense (UFF), which act in different areas, about the main types of business performance indicators applicable to Micro and Small Enterprises. To accomplish this, a theoretical background was applied on performance indicators and on the Balanced Scorecard model. Besides that, the authors have conducted interviews with doctors of UFF in the areas of financial, customer, internal business process and learning and growth to develop a set of fifteen indexes. These fifteen indicators compose the set of performance indicators for MSE. It was concluded that the objectives were achieved and this study may well contribute to the academic community and to society, as so for businesses by presenting a set of introductory performance indicators for those micro and small companies that do not have this practice.
\end{abstract}

Keywords: Balanced Scorecard; Micro and Small Enterprises; Indicators of Business Performance.

\section{INTRODUCTION}

Pamplona et Ottoboni (2001) stated that Brazilian companies, regardless of size or structure, are facing great challenges and changes that contribute to increased risk and uncertainty, making the management of the companies a very complex and challenging activity. For Rocha et Oliveira (2006 ), firms with higher chances of success will be those with greater responsiveness - launching new goods and services faster, meeting demands and achieving reliability.

By realizing these challenges, the authors agree that they are monitoring methods and indicators of efficient performance to guide decisions aligned with strategic goals, visions and missions that the organizations needed.

While looking for a performance indicator system that allows companies to have a correct orientation, Kaplan and Norton introduced the Balanced Scorecard (BSC), where financial measures are complemented by non-financial measures and relations of cause and effect between them are established. The tool is a management system that shows the company's strategy in performance measures, allowing the strategy to become part of the day to day management of the company. It also expands the vision of the company beyond the annual budget, introducing management tools the prospect of present results and its future impact.

Researchers of the Balanced Scorecard use mostly conglomerates as models of their reports of practical and theoretical applications, and according to Kaplan et Norton (1997), the system should reflect the structure of the organization to which the strategy was formulated. So, the same would be applied to corporations, joint ventures, departments of support in companies and business units, public companies and nonprofit institutions. However, it is seen that, in small businesses, there is a hardship of following the steps proposed by the BSC precursors, resulting in the need of preparing a proposal that considers the characteristics and relevant resources available to small businesses. 
This study is grounded in the perception of specialists from UFF in the areas of financial, customer, internal business process and learning and growth on the performance indicators for micro and small enterprises.

In this sense, the goal of this research is to develop a set of specific performance indicators for micro and small enterprises. To achieve this goal, this study unfolds into three specific objectives: (1) the review of literature on performance indicators; (2) the conduct of interviews with teachers in the areas of financial, customer, internal business process and learning and growth about performance indicators for micro and small enterprises; and (3) the development of a specific set of performance indicators for micro and small enterprises.

\section{METHODS}

Primarily, a study of performance indicators - focused on the Balance Scorecard - was performed. This bibliographical study reveals that the performance indicators are useful for small business; and it presents the main model of performance indicators for business management - the Balanced Scorecard; moreover, it clarifies concepts on MSE and its main features.

The second stage is grounded in the perception of PhDs of the Federal Fluminense University, who teach and research in the areas of financial, customer, internal business process and learning and growth, with the focus of raising, in the opinion of such teachers, which would be the most appropriate performance indicators for MSE.

The results found in this second step, together with the targeted prospects of the Balanced Scorecard were compiled for a second interview in order to verify the agreement of the results searched by the teachers.

The third and final phase is the compilation of the results of the second stage and the analysis of them to assist in developing a set of indicators for this important business segment.

\section{PERFORMANCE INDICATORS}

According to Resnik (1991, p.3), smart management is crucial for the survival and the success of enterprises. "Smart" management is understood as the ability to understand, manage and control the company based on the critical attention of the administration for the decisive factors that are responsible for the success and the survival of the company.

This "critical attention" for making decisions comes from performance indicators, according to PNQ (2007), "indicators are data or numerical information that quantifies the inputs (resources), outputs (products) and performance of processes, products and the organization as a whole. The indicators are used to monitor and to stimulate managers to improve results over time". Thus, the indicator allows the company to obtain information about the reality, it can synthesize the information and retain only the essential aspect analyzed for the quantitative complex phenomena to become understandable (FIELDS et MELO, 2008).

Pace.et al.,(2003) states that a good administrator controls the performance of systems under their responsibility with the help of indicators, occurring combination of factors that lead to decision making and the destiny of the organization, which just confirms the affirmation of Globerson et Frampton: "you can't manage what you can't measure" (apud Fernandes, 2004, p.4) .

Next, we shall discuss the performance indicators model, the Balanced Scorecard (BSC), a revolutionary instrument that Kaplan \& Norton (1997) developed .

\subsection{Balanced Scorecard}

The Balanced Scorecard was created to meet the need of the organization for dynamics, holistic and consistent information with their needs and strategies. According to Soares (2001), this tool was created to develop a new set of performance measures because financial measures were becoming obsolete - which hurt the organization's ability to create future economic value. Thus, in addition to financial measures, other measures also came to be regarded as the precursors of the tool as pointed out by, Kaplan et Norton ( 1997 , p.19):

The Balanced Scorecard is a new instrument that incorporates the derived measures of the strategy. Without belittling the financial measures of past performance, it incorporates the drivers of future to the financial performance. These vectors, which include the perspectives of customer, internal processes and learning and growth, are born of a conscious effort and rigorous translation of organizational strategy into objectives and tangible measures.

So, this tool is a set of measures consistent with the company's strategies, aligning individual, organizational and interdepartmental initiatives to achieve global optimum.

Nunes $(2008$, p.66) summarizes the system states that the BSC "translates the strategic vision of a company's goals in tangible measures" based on four different perspectives which complement, represent the balance between external and internal indicators, form a single and interdependent whole within interrelated objectives and indicators and form a flow of cause and effect, starting from the perspective of learning and ending in the financial perspective. 
The perspectives that Kaplan et Norton (1997) propose are: (1) finance, (2) internal processes, (3) learning and growth, and (4) customers, as shown in Figure 1.

Figure 1: Translating Vision and Strategy - The Four Perspectives (KAPLAN \& etNORTON, 1997, p.10).

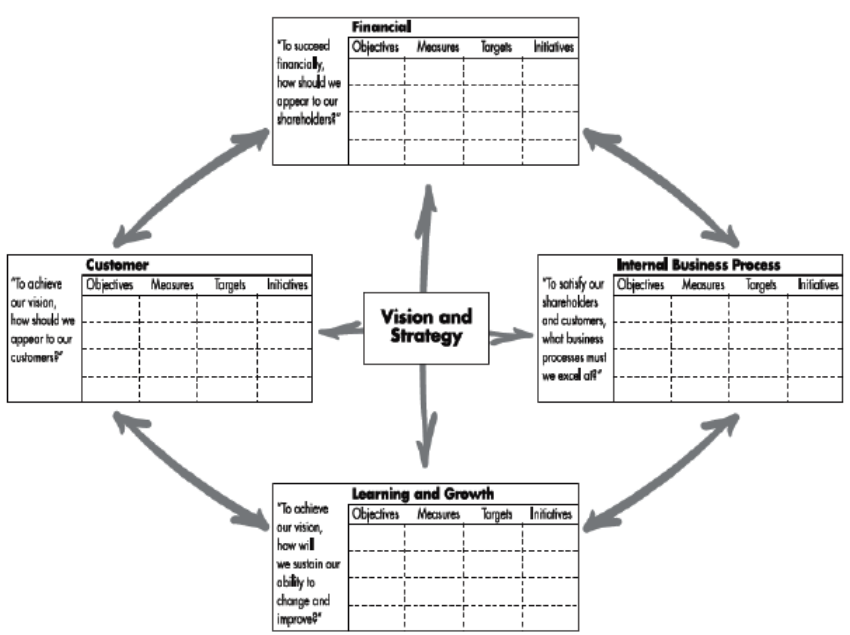

With this tool, managers assess whether their business units create value for current and future customers, if it improves capabilities and internal investments in personnel, systems and procedures to leverage future performance (Kaplanet Norton, 1997, p .8).

Kaplan et Norton (1997) admit that the vectors of success from the perspective of learning and growth are more generic and less developed compared to other perspectives and point out the importance of the development of custom indicators for this .

Since their means of success are not as developed as others, it is presented here other models of indicators the social indicators - of which, among other perspectives, will also review the company's commitment towards its employees and its growth .

After introducing the logic of perspective, we suggest reading the book "The Strategy in Action : the Balanced Scorecard" by Kaplan and Norton, because this study did not deepen in the four BSC perspectives .

A brief description of the MSE will be presented as follows. The focus of this study is in order to show how they relate to the administrative tools presented.

\section{MICRO AND SMALL ENTERPRISES}

Almeida et Marçal (2008) argue that increased competition encourages companies to seek innovations aiming to achieve excellence. As shown in this study, excellence can be achieved through performance management - which means creating visions for the future, plans, strategizing, among others - for any type of organization, including for Micro and Small Enterprises.
Focusing on this type of organization, Nunes (2008) et Almeida (2005) agree that there are many concepts of MSE. These are generally considered quantitative criteria - such as the number of employees or the annual sales gross-qualitative criteria - such as low-skilled personnel or difficulties in obtaining financing - or both. IBGE (2001) points out that the use of heterogeneous concepts stems from the fact that the purpose and objectives of the institutions that promote its framework are distinct (regulatory, credit, studies, etc...)

Leone (1998) delves further in characterization of MSE and says that these are more centralized, with simple organizational structure (due to the complexity and costs) where the absence of hierarchical levels allows direct contact between employees and the company. This last fact helps in the formation of a strong organizational culture.

The author emphasizes the bass control on the external environment and the influence of uncertainty in the internal aspects of strategic behavior:

\begin{abstract}
The social and economic environment drives small and mid- managers to adopt a form of monolithic administration, because the delegation of authority and rationality of forms of control can lead to large losses. For the manager, it is preferable to act alone and guided by his sensibility rather than by technical means of administration provided by Science for enterprises with a sophisticated administrative organization (LEONE , 1998, p. 92).
\end{abstract}

In MSE, the strategy is intuitive and somewhat formalized, operating under a logic of reaction and adaptation to the environment, due to the absence of formal planning (although the manager has an undeclared strategic vision) which leads to the following characteristic: customization of management in the person of owner - the manager himself, discusses with clients to meet needs and preferences or explains the specificity of his product.

The decision is also grounded in the manager within a short-term perspective, since he does not have the time or skills necessary for a more analytical and strategic posture. The value system of the owner/manager is the same for decision-making and policy-making of the enterprise, turning the company into an extension of the manager himself.

In recent years, researchers have tried to understand the problems faced by these organizations because they have realized the role of these kinds of companies in generating new jobs, and their social importance. According SEBRAE, $99.2 \%$ of enterprises in Brazil are classified as MSE and these are responsible for $57.3 \%$ of employment in the country, according to the Statistics Collection of Micro and Small Enterprise (SEBRAE 2005, p.11). With this argument, Almeida et Marçal (2008) highlight the undeniable importance of the micro and small enterprises in the economy and worry 
Brazilian Journal of Operations \& Production Management

Volume 12, Número 2, 2015, pp. 298-305

DOI: 10.14488/BJOPM.2015.v12.n2.a9

about the lack of studies on Planning, Implementation and Strategic Control of these kinds of companies, agreeing with Leone (1998).

But the question is: What is the formula for the success of MSE?

The answer is still unknown, but researchers in management have realized that these are not the same management principles on a smaller scale used by large companies.

For these reasons, this study proposes to use a method that considers the limitations and particularities of MSE in order to create a unique tool for these organizations. Following, the results of the survey will be presented.

\section{RESULTS OF THE SURVEY}

At this time, the development and the results of interviews with specialists will be presented, to search for a set of indicators, trampled on the principles of the Balanced Scorecard for Micro and Small Enterprises.

After studying the topics "Performance Indicators" and "Micro and Small Enterprises", the first step of this activity was to interview PhD professors from four areas of management, who teach and research on financial, customer, internal business process and learning and growth. The results of these interviews are shown in Table 1.

Table 1: Results of the first interview

\begin{tabular}{|c|l|}
\hline \multicolumn{1}{|c|}{ BSC } & \multicolumn{1}{c|}{ Indicators } \\
\hline \multirow{4}{*}{ FINANCIAL } & Asset Turnover \\
\cline { 2 - 2 } & Net Margin \\
\cline { 2 - 2 } & Costly debt \\
\cline { 2 - 2 } & Operating cycle \\
\hline \multirow{4}{*}{ CUSTOMER } & Margin of the compound Relevance Product \\
\cline { 2 - 2 } & Marketing Efficiency \\
\cline { 2 - 2 } INTERNAL & Growth rate \\
BUSINESS & Absenteeism \\
& Accuracy in stock \\
LEARSING AND & Total investment in Remuneration \\
GROWTH & Rate Distributing information \\
& Rate Autonomy \\
& Training
\end{tabular}

With these results, the author has developed a questionnaire to check the level of agreement between other PhD professors of the same areas (financial, customer, internal business process and learning and growth).
As a result of this questionnaire, the author has obtained as a suggestion from one of the PhD professors to use items of "Reasons for Closure of Micro and Small Enterprise of SEBRAE 2005". According to the researcher, the use of these items would be a way of better methodologically supporting this research. It is noteworthy that the reason for using the 2005 booklet is justified, according to this professor, the fact that the methodology used by SEBRAE by the year 2005 was more well-structured than for the following years.

Understanding the suggestion of the teacher, the author has elaborated Table 2. This table shows the intersection between the "Reasons for Closure of Micro and Small Enterprise of SEBRAE 2005" and the BSC. It is noted that not all of SEBRAE's items were related to BSC perspectives - justified by the fact that there is no possibility to create indicators with the excluded items (Continued disinterest in Business; Economic Crisis in the Country; Bad Company Location; and Taxes). Summing up, these items are not measurable or are not directly related to business management.

Table 2: Reasons for Closure of Micro and Small Enterprise x BSC.

\begin{tabular}{|c|c|c|}
\hline REASONS SEBRAE & BSC & $\begin{array}{c}\text { REASONS SEBRAE } x \\
\text { BSC }\end{array}$ \\
\hline Lack of Working Capital & \multirow[t]{6}{*}{ FINANCE } & $\begin{array}{l}\text { Lack of Working } \\
\text { Capital }\end{array}$ \\
\hline Low Income & & Low Income \\
\hline Financial difficulty & & Financial difficulty \\
\hline Lack of Credit & & \multirow[t]{3}{*}{ Lack of Credit } \\
\hline $\begin{array}{l}\text { Disinterest in } \\
\text { Continued Business }\end{array}$ & & \\
\hline $\begin{array}{l}\text { Economic Crisis in the } \\
\text { Country }\end{array}$ & & \\
\hline Bad Payers & \multirow{4}{*}{$\begin{array}{l}\text { CLIENTS AND } \\
\text { MARKET }\end{array}$} & \multirow[t]{2}{*}{ Bad Payers } \\
\hline Bad Company Location & & \\
\hline competition & & \multirow[t]{2}{*}{ Competition } \\
\hline $\begin{array}{l}\text { Disagreements With } \\
\text { Partner / Owner }\end{array}$ & & \\
\hline bureaucracy & \multirow{2}{*}{$\begin{array}{l}\text { INTERN } \\
\text { PROCESS }\end{array}$} & bureaucracy \\
\hline Lack of Customers & & Lack of Customers \\
\hline Lack of skilled labor & \multirow{3}{*}{$\begin{array}{c}\text { LEARNING } \\
\text { AND GROWTH }\end{array}$} & \multirow[t]{2}{*}{ Lack of skilled labor } \\
\hline Taxes / charges / taxes & & \\
\hline $\begin{array}{l}\text { Lack of Knowledge } \\
\text { Management Area }\end{array}$ & & $\begin{array}{l}\text { Lack of Knowledge } \\
\text { Management Area }\end{array}$ \\
\hline
\end{tabular}

After the development of this table, the author has searched on the theoretical background, and again with the PhD professors, for indicators that could have been useful for the MSEs and which are related to SEBRAE's items. As a result, the author has set Table 3, which summarizes the indicators proposed by UFF's PhD professors for MSEs, based on SEBRAE's reasons for closing the MSE. 
Table 3: Indicators resulting from the Reasons for Closure of Micro and Small Enterprise

\begin{tabular}{|l|l|}
\hline \multicolumn{1}{|c}{ BSC } & \multicolumn{1}{c|}{ Indicators } \\
\hline FINANCE & Asset Turnover \\
\cline { 2 - 2 } & Net Margin \\
\cline { 2 - 2 } & Return on Equity \\
\cline { 2 - 2 } & liquidity Drought \\
\cline { 2 - 2 } & Medium Term Pay \\
\cline { 2 - 2 } & Average Collection Period \\
\hline CLIENTS AND MARKET & market efficiency \\
\cline { 2 - 3 } & Default Rate \\
\cline { 2 - 2 } & Rate of return \\
\cline { 2 - 2 } & Customer retention \\
\hline INTERN PROCESS & \% Failed Service \\
\cline { 2 - 3 } & Rate Rework \\
\hline \multirow{5}{*}{ LEARNING AND GROWTH } & \% of computerization \\
\cline { 2 - 2 } & Rate Distributing Information \\
\cline { 2 - 2 } & Training \\
\hline
\end{tabular}

Table 3 highlights the final result of this research, which consists of only fifteen indicators, which are sufficient and essential for the management of MSE.

The following discussion will present the results obtained in the theoretical background and the results of survey research with UFF's PhD professors.

\section{SEARCH RESULTS ANALYSIS}

In this topic, a reflective analysis of the indicators defined in the research will be presented, exposing their meanings and justifying how truly viable for Micro and Small Enterprises they are.

As noted earlier in this paper, the development of a set of performance indicators that give the organization a correct orientation is essential to the success of any organization. Various models were created aiming at this "correct guidance". However, these models show a wide range of indicators to be chosen by the organizations, according to their needs, to better satisfy them.

In this sense, analyzing the reality of Micro and Small Enterprises, we realize that there are many indicators that have no use or no interest on the part of the micro manager, to invest time and resources in raising rates. This clarification can be grounded on the assertion of Leone (1998, p.92):

For the manager, it is preferable to act alone and guided by their sensitivity than by technical means of administration provided by science for enterprises with a sophisticated administrative organization.
Moreover, the fact is that in many cases the lack of data or incorrect data - justified by intuitive and little formalized strategy or the simplicity of the information of MSE (Leone, 1998) system - can lead to micro and small organizations to show erroneous indicators, invalidating the real goal of these: correct orientation.

Besides that, the lack of "correct guidance", the intuitive strategy and low planning are, directly and indirectly, some of the failures of MSE factors. In this sense, the use of selected indicators that are viable and of easy application can be thought in a way to introduce the practice of planning and strategy that is so important in this type of organization in Brazil - "corresponds to $99.2 \%$ of companies active in the country [...], employs $57.2 \%$ of workers with formal relationship and accounts for $20 \%$ of national GDP" (FERRONATO 2011, p.2).

Interviews with experts in the four areas of administration resulted in a set of indicators essential to Micro and Small Enterprises, which can be interpreted as an introductory set for performance management for a type of organization characterized by the lack of this management tool.

This set of indicators contains only fifteen indexes, divided into the four perspectives of BSC, as reported in the Table 4.

Tabela 4: Final Set of Perfomance Indicators Detailed

\begin{tabular}{|c|c|}
\hline BSC & Indicators \\
\hline \multirow{6}{*}{ FINANCE } & Net Margin = Net Profit $/$ Revenue \\
\hline & $\begin{array}{l}\text { Medium Term Pay = (Eastern Providers / Cost of } \\
\text { Goods Sold) } \times 360\end{array}$ \\
\hline & $\begin{array}{l}\text { Average Collection Period = (receivables } / \text { net } \\
\text { sales) } \times 360\end{array}$ \\
\hline & $\begin{array}{l}\text { Quick Ratio = (current assets - inventory) / current } \\
\text { liabilities }\end{array}$ \\
\hline & Asset Turnover = Net Income / Total Assets \\
\hline & Return on Equity = Net Income / Equity \\
\hline \multirow{4}{*}{$\begin{array}{l}\text { CLIENTS } \\
\text { AND } \\
\text { MARKET }\end{array}$} & $\begin{array}{l}\text { Default Rate = Overdue Accounts Receivable / } \\
\text { Accounts Receivable }\end{array}$ \\
\hline & $\begin{array}{l}\text { Customer Retention = number of customers } n+1 / \\
\text { year No amount of customers }\end{array}$ \\
\hline & $\begin{array}{l}\text { Rate of Return = returned amount / quantity } \\
\text { produced }\end{array}$ \\
\hline & $\begin{array}{l}\text { Efficient marketing = sales volume of the product - } \\
\text { finished goods inventory / sales forecast }\end{array}$ \\
\hline \multirow[b]{2}{*}{$\begin{array}{l}\text { INTERN } \\
\text { PROCESS }\end{array}$} & Rate Rework = rework / total output \\
\hline & $\begin{array}{l}\text { \% Failure Care = unserved customers due to lack of } \\
\text { transportation or product / total clients served }\end{array}$ \\
\hline
\end{tabular}




\begin{tabular}{|l|l|}
\hline \multirow{2}{*}{$\begin{array}{l}\text { LEARNING } \\
\text { AND }\end{array}$} & $\begin{array}{l}\text { \% of computerization =\% Computerization of } \\
\text { Activities / Total Activities }\end{array}$ \\
\cline { 2 - 3 } & $\begin{array}{l}\text { Rate Distributing Information = hours invested in } \\
\text { monthly meetings with all employees / total hours } \\
\text { worked in the month }\end{array}$ \\
\cline { 2 - 2 } & $\begin{array}{l}\text { Training = Time (in hours) Invested in training per } \\
\text { month / total hours worked per month) }\end{array}$ \\
\hline
\end{tabular}

Kaplan et Norton (1997) state that the financial perspective is to focus on the goals of other perspectives, so that all measures should result in improved financial performance. This view shows the financial performance of the organization and is the main goal and measure of other perspectives.

In this matter, the first indicator set is the developed "Net Margin". Matarazzo (2010) states that this profitability indicator shows how much profit the company gets for every hundred monetary units sold, which measures the overall efficiency of the organization.

The second financial index is "Medium Term Pay" indicates the number of days that the company takes to pay suppliers. This index indicates the amount of time that the company is funded by leading non-pecuniary liability (suppliers).

The third financial indicator is the "Medium Term Receipt", which reveals how many days the company expects to receive sales (time elapsed between the date of sale and receipt), in which the ideal is to receive duplicates of sales before to pay the bills of purchases.

The fourth index of this perspective is the "quick ratio", which describes the percentage of short-term debt that can be settled through cash resources available (Nunes, 2008).

The fifth index of this perspective is the "Asset Turnover", which shows the quantity sold for each monetary unit of total investment (Matarazzo, 2010). Matarazzo (2010) states that the success of a particular company depends on an adequate volume of sales and this is related to the amount invested.

The sixth and final content of this perspective is the "Return on Equity", which indicates the net return of own funds invested in the company, i.e., the owners get profit monetarily for each unit (NUNES , 2008; MATARAZZO 2010 ) .

Kaplan et Norton (1997) argue that to improve financial performance in the long term, organizations need to develop products and services valued by customers. In this sense, the perspective of customers and market aligns the measures of results to customers (satisfaction, loyalty, retention, acquisition, profitability).

To this goal, the first indicator of Table 4 is the calculation of the "Default Rate". This index shows the manager the level of customer default, which may assist him in deciding on lending and action on their charging policies. Manage the provision of credit and, thus, the risk involved is essential to increase sales, maintain effective policies of credit, guarantee receipt, keep the flow of predictable and reliable cash and reduce costs in the release and recovery of credit (SEBRAE 2013).

The second index of this perspective is "Customer Retention", pointing to varying the amount of customers in the year, it is important for the manager to see if there is an increase, decrease or stability of customers during the period.

The third indicator from the perspective of customers and market is the "Rate Returns", pointing out to the manager the amount of products returned by customers in relation to the quantity produced (or sold if in retail). This index shows the degree of acceptance, compliance, and customer satisfaction for the product, giving an opportunity for the company to investigate possible problems and improvements in the production or for seeking new suppliers who provide the highest quality of material.

The fourth and final content refers to "marketing efficiency", which shows to the manager if its market performance is satisfactory - if sales are consistent with expected and produced. In the context of micro managers, the adoption of this index will analyze its demand forecast, check if it is producing and selling the amount that the market requests.

So to fulfill the expectations of customers and the market as a whole, internal processes must be aligned with the organization's strategy through a complete chain of values of the internal processes. This string is displayed in the internal perspective of the BSC, in which managers can view critical processes to achieve the objectives of customers and shareholders.

For micro and small business, which were discussed earlier, generally do not have a well defined strategy, the proposed indicators are intended to stimulate critical thinking regarding the manager's internal planning.

The first indicator is the "Rework Rate", which points to the manager the level of error in the process, how much was wasted, for i.e., failure in the production process generating burden to the organization.

This interpretation is also valid for the second index found - "Percentage of Failure in Service", which can point out flaws in the production or sales of the business process, encouraging the manager to seek optimization of the process or the training vendor, i.e..

Thus, for these indexes are at an acceptable level, it is essential to invest in learning and growth - the fourth perspective of the BSC. Kaplan et Norton (1997) point out 
that this type of investment is essential for the excellence in performance of organizations in the long run, being necessary to invest both in training and in research as in infrastructure.

In this sense, the first indicator of learning and growth perspective is the "Percentage of Informatization", showing the manager, all activities undertaken by the organization, the amount of computerization of these activities.

The second indicator of this perspective is the "Rate Information Attainment", an indicator that shows how much the manager invests in meetings with employees - an important way to maintain effective communication.

The third and final indicator of the learning and growth perspective is "Training", which indicates the relationship between hours worked and hours spent in the month. This indicator is directly related to the internal performance of the organization - as with trained professionals, for the processes that are best run have better financial results.

With this last indicator, one can clearly see the connection between the four BSC perspectives, as each perspective contributes to the optimization of the other.

This set of indicators is neither unique nor immutable, just as previously stated; it's a set of introductory indicators for MSEs that have not yet joined the practice of performance measurement for "correct guidance" for micro and small managers.

To complete this research, the next item - conclusion presents considerations on the results shown, beyond the final considerations of the research. Also in this chapter, recommendations are made for academic and professional field.

\section{CONCLUSION}

This study was aimed to present a set of indicators in BSC perspectives, for Micro and Small Enterprises grounded in UFF's experts' opinions.

From the analysis of the results, it has been argued that non-use of performance indicators for the MSE is due to its intuitive strategy and the low level of planning, but the need for a "correct guidance» makes this tool necessary as an introductory form of planning and strategy to micro and small managers.

It is noteworthy, therefore, that the result reached in this study is not a model that fits for all Micro and Small Enterprises, as each company has its own indicator system. However, the result achieved is for a MSE without a system of indicators, so the manager can start measuring his business results based on the performance indicators for MPE system's developed here.
Therefore, it can be stated that the objectives have been met and that this study may contribute to the academic community as a further study on the measurement of performance for the MSE, and to the business society for presenting a set of introductory performance indicators for micro and small organizations that do not perform this business practice.

\section{REFERENCES}

Almeida, S. 2005 . Adequacy Of Techniques And Tools For Strategic Management in Micro and Small Enterprises: a proposal. Master Thesis. Federal Technological University of Paraná, Ponta Grossa. DOI= http://www.pg.utfpr.edu.br/ dirppg/ppgep/dissertacoes/arquivos/18/dissertacao.pdf

Almeida, S.; Marçal, R. M. F.. 2006. Tools and Techniques for Strategic Management in Micro and Small Enterprises: A Proposal. In Annals XIII SIMPEP - Bauru, SP, Brazil, 2006, vol XIII. ISSN 1809-7189.

Fields, L. M.; Melo, D. A. 2008. Performance Indicators of Environmental Management Systems (EMS): a theoretical study. Prod., Dec 2008, vol.18, no.3, p.540-555. ISSN 01036513

Fernandes, D. R. 2004. A contribution to the construction of indicators and their importance to business management. FAE Magazine, Curitiba, v.7, n.1, p.1-18, Jan. / June 2004.

IBGE. Micro and Small Business Enterprises and Service in Brazil. Studies \& Research: Financial Information 1, 2001 DOI = http://www.ibge.gov.br/home/estatistica/economia/ microempresa/microempresa2001.pdf

Kaplan, R. S., Norton, D. P. 1997. The strategy into action: Balanced Scorecard. Rio de Janeiro: Campus.

Leone, N. M. P. C. G. 1998. The characteristics of small and medium enterprises . Journal of Management, vol . 34 , n.2 , p.91 -94.

Matarazzo, D. C.2010. Financial Analysis of Balanc: managerial approach . 7th ed. Sao Paulo : Atlas. ISBN : . 978-85-224-5692-5.

Nunes, A. V. S. 2008 . Performance indicators for micro and small enterprises : a survey of the MSE associated with microempa of Caxias do Sul / RS. Master Thesis. 107p . University of Caxias do Sul, Caxias do Sul. DOI = http://tede. ucs.br/tde_busca/arquivo.php?codArquivo $=202$

Ottoboni, C.;Pamplona, E. O. 2001. Research Proposal to Assess the Need to Measure the Financial Performance of Micro and Small Enterprises. XXI ENEGEP October. Salvador, Bahia.

Pace, E. S. U.; Basso, L. F. C.; Silva, M. A. 2003. Performance indicators such as value drivers . Rev. adm . contemp . vol.7, 
no.1 , p.37- 65 . ISSN 1415-6555

Ramos, E. F. 2012 . Identifying key factors for assessing excellence in management in Brazil - an essay PNQ model . Master Thesis 115p . Fundação Getúlio Vargas (FGV), São Paulo, SP. DOI = http://bibliotecadigital.fgv.br/dspace/ handle/10438/9837

Resnik, P. 1991. The bible of small and medium businesses. São Paulo: Makron Books.

Rocha, H. M.; Oliveira, U. R. 2006. Balanced scorecard as a source of competitive advantage for organizations: a literature review. Annals XIII SIMPEP - Bauru , SP , Brazil, vol XIII . ISSN 1809-7189

Silva, A. T. C. 2007. Accounting . Accounting / César Augusto Silva Tiburcio . - Florianópolis : Department of Management Sciences / UFSC. 264p DOI = http://cead.ufpi. $\mathrm{br} /$ conteudo/material_online/disciplinas/contabilidade/ textos/Contabilidade_final_revisado.pdf

Soares, C. D. R. 2001 . Development of a systematic development of Balanced Scorecard for small businesses. 2001. 122p . Master Thesis - Federal University of Rio Grande do Sul, Porto Alegre, $\mathrm{DOI}=$ www.lume.ufrgs.br 